DOI: https://doi.org/10.31933/jemsi.v3i2

Received: 2 November 2021, Revised: 15 November 2021, Publish: 27 Desember 2021

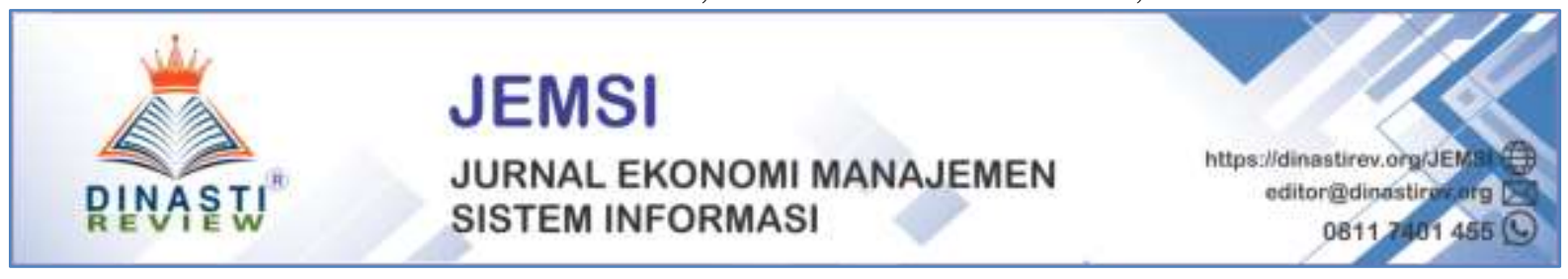

\title{
PERANAN DATA WAREHOUSE, SOFTWARE DAN BRAINWARE TERHADAP PENGAMBILAN KEPUTUSAN (LITERATURE REVIEW EXECUTIVE SUPPORT SISTEM FOR BUSINESS)
}

\author{
Sri Wahono ${ }^{1}$, Hapzi Ali ${ }^{2}$ \\ ${ }^{1)}$ Mahasiswa Fakultas Ekonomi, Universitas Bhayangkara Jakarta Raya, email: sriwahono099@gmail.com \\ ${ }^{2}$ Dosen Fakultas Ekonomi, Universitas Bhayangkara Jakarta Raya, email: hapzi@dsn.ubharajaya.ac.id
}

\section{Corresponding Author: Sri Wahono ${ }^{1}$}

Abstrak: Dalam kegiatan pengambilan keputusan, seorang manajer membutuhkan informasi, karena dengan informasi maka akan ditempuh sebuah pemecahan masalah yang efektif dan efisien dalam memenuhi kebutuhan yang ada. Dengan sistim informasi dapat merampingkan dan mempercepat waktu reaksi terhadap perubahan lingkungan, dan membantu dalam mencapai kompetitif perusahaan. Software (DSS aplikasi) ini berfungsi dalam memberikan sebuah perintah untuk komputer, agar komputer tersebut berfungsi secara optimal - sinkron dengan menggunakan kemauan si user atau pengguna. Sedangkan data Warehouse adalah tempat penyimpanan data perusahaan atau institusi yang terpusat dan terintegrasi, serta disusun sedemikian rupa, sehingga sangat mendukung proses pengambilan keputusan, dengan memberikan input pada software aplikasi. Sebuah Software aplikasi membutuhkan data warehouse agar dapat menjalankan prosesnya dengan akurat. Brainware yang handal dan professional akan melancarkan semua kepentingan bisnis, dengan dukungan setiap pengambilan keputusan. Setiap pelaku bisnis selalu berkompetisi dengan pelaku bisnis yang lain. Pemanfaatan teknologi informasi dalam hal ini sistem pendukung keputusan menjadi strategis karena dimanfaatkan tidak hanya untuk operasional perusahaan tetapi juga untuk memenangkan persaingan. Peranan Sistim informasi dalam suatu perusahaan menjadi penting karena kemampuannya membantu manajemen dalam proses pembuatan keputusan ekonomi.

Keyword: Data Warehouse, Software, Brainware dan pengambilan keputusan.

\section{PENDAHULUAN}

\section{Latar Belakang Masalah.}

Sistem informasi merupakan sebagai satuan komponen yang saling berhubungan yang mengumpulkan , memproses, menyimpan, dan mendistribusikan informasi untuk mendukung pengambilan keputusan dan kendali dalam suatu perusahaan. Selain itu sistem informasi juga membantu para manajer untuk meneliti permasalahan, memvisualisasikan pokok-pokok yang kompleks dan menciptakan produk produk baru. Dapat dikatakan sistem informasi adalah 
serangkaian prosedur formal di mana data dikumpulkan. Sistem informasi adalah paduan dari berbagai resources baik hardware, software, netware, brainware, dan data. Dalam sistem informasi juga ada input, model, proses, output, penyimpanan dan kontrol, sehingga sistem informasi dapat digunakan untuk merencanakan, mengolah, mengendalikan serta meracik data dalam suatu organisasi berdasarkan critical sukses untuk menentukan keberhasilan perusahaan.

Definisi yang jelas dari Sistim Informasi adalah "suatu sistem yang membantu perusahaan mengubah atau mengubah strategi bisnis mereka dan / atau struktur. "Hal ini biasanya digunakan untuk merampingkan dan mempercepat waktu reaksi terhadap perubahan lingkungan dan membantu dalam mencapai kompetitif keuntungan. Fitur utama dari ISS Strategis adalah sebagai berikut:

1. Sistem pendukung keputusan yang memungkinkan untuk mengembangkan pendekatan strategis untuk menyelaraskan ISS (Intelligent Support System) atau IT dengan strategi bisnis organisasi;

2. Terutama Perusahaan solusi perencanaan sumber daya yang mengintegrasikan / menghubungkan proses bisnis untuk memenuhi tujuan perusahaan untuk optimalisasi sumber daya perusahaan.

3. sistem database dengan "data warehouse" kemampuan untuk membuat penggunaan terbaik dari perusahaan yang tersedia informasi untuk pemasaran, produksi, promosi dan inovasi. Sistem ISS juga memfasilitasi identifikasi strategi mengumpulan data untuk membantu mengoptimalkan peluang database pemasaran.

4. The real-time ISS yang berniat untuk mempertahankan cepat-respon dan indikator kualitas.

Proses data terdistribusi merupakan suatu konsep penyebaran komputer dan peralatan, perangkat lunak dan data yang dihubungkan dengan alat komunikasi dengan perangkat yang ada pada lokasi lain. Proses data terdistribusi sudah menjadi keharusan dengan kemajuan sistem komunikasi pada saat ini khususnya oleh komponen brainware. Tulisan ini meninjau peranan brainware dalam sistem informasi manajemen. Tulisan ini dimulai dengan melakukan reviu tentang konsep teori atau kajian teori untuk memberikan gambaran mengenai brainware dan sistem informasi manajemen, kemudian dilanjutkan dengan ulasan mengenai peranan brainware dalam sistem informasi manajemen dan diakhiri dengan mengajukan suatu proposisi

Artikel ini membahas peranan data warehouse, software dan braiware terhadap pengambilan keputusan.

\section{Rumusan Masalah.}

Berdasarkan latar belakang, agar lebih fokus pada kajian pustaka dan hasil serta pembahasan nanti, maka di rumuskan masalah yang akan di bahas pada artikel literature review, yaitu:

1. Apakah data warehouse memiliki hubungan dan berpengaruh terhadap pengambilan keputusan.

2. Apakah software memiliki hubungan dan berpengaruh terhadap pengambilan keputusan.

3. Apakah brainware memiliki hubungan dan berpengaruh terhadap pengambilan keputusan. 


\section{KAJIAN TEORI}

\section{Data Warehouse}

Definisi Data menurut, (Gunadi \& Widianto, 2020) adalah bahan mentah yang perlu dilakukan pengolahan sehingga menghasilkan informasi atau keterangan, baik kualitatif maupun kuantitatif yang menunjukkan fakta sehingga dapat memberi manfaat bagi peneliti atau memberi gambaran kepada peneliti tentang kondisi atau suatu keadaan. Sedangkan informasi adalah sekumpulan data yang sudah diolah sehingga menghasilkan suatu Analisa untuk digunakan oleh pihak yang membutuhkan.

Mengutip dari Jurnal (Muhammad Rifqi, Rusdah, Moedjiono, menurut (Gunadi \& Widianto, 2020) ) berjudul Penerapan Data Warehouse pada PT AL dengan menggunakan Metode Kriptografi. Data warehouse adalah sebuah basis data komprehensif yang mendukung semua analisis keputusan yang diperlukan oleh suatu perusahaan dengan menyediakan ringkasan dan rincian informasi. Penyimpanan sistem informasi pada data warehouse terbagi menjadi beberapa jenis berdasarkan arsitektur teknologi informasinya, adalah:

- Arsitektur tersentralisasi Penyimpanan data yang tersentralisasi tersimpan di komputer yang memiliki kapasitas simpan yang besar dan mampu memproses jutaan data transaksi. Yang saat data tersebut diperlukan maka komputer tersebut bisa merespon dengan cepat. Tipe penyimpanan sentralisasi ini biasanya digunakan oleh perusahaan yang semua datanya disimpan tersentral, tidak memiliki anak cabang karena hanya kantor utama, atau melihat dari sisi sekuritas data perusahaan disentralkan.

- Arsitektur desentralisasi Penyimpanan data yang tersebar, yang setiap perangkat tersebut antara satu sama lain terhubung dan memiliki spesifikasi yang serupa, desentralisasi ini sering disebut dengan peer to peer. Biasanya sistem yang terdistribusi seperti ini digunakan untuk perusahaan yang memiliki banyak sekali anak cabang. Arsitektur seperti ini secara biaya lebih murah, tidak ada ongkos perawatan, cepat dan mudah diakses, tanggung jawab sesuai komputer tersebut berada, ada data cadangan untuk back up. Semua dapat dicapai dengan baik apabila perancangan dan standard control untuk arsitektur desentralisasi sudah dibuat secara jelas dan terarah.

- Arsitektur client/server Arsitektur ini mengarahkan konektifitas komputer, client yang dimaksud adalah software yang menerima perintah untuk menjalankan suatu aplikasi yang terkoneksi ke server, sedangkan server tempat menyimpan data informasi yang diminta oleh client. Contoh sederhana: data $\mathrm{X}$ disimpan pada server untuk akses dan permintaan data tersebut butuh akses yang disetting atas client yang berkaitan atau aplikasi yang diinstall pada server akan tetapi dapat di remote server oleh komputer yang memiliki akses untuk membuat aplikasi pada server tersebut.

- Arsitektur cloud Arsitektur cloud gabungan antara arsitektur desentralisasi dan sentralisasi tapi semuanya berbasis Web Base. Mengutip dari IEEE Interner Computing suatu paradigma di mana informasi secara permanen tersimpan di server di internet dan tersimpan secara sementara di komputer user (client) termasuk di dalamnya adalah desktop, komputer tablet, notebook, handheld, sensor-sensor, monitor dan lain-lain.

Data warehouse adalah koleksi data yang mempunyai sifat subject-oriented, Integrated, nonvolatile, dan time-variant untuk mendukung proses pengambilan keputusan dalam manajemen. Menurut Mannino, data warehouse adalah tempat penyimpanan data terpusat, 
dimana data dari basis data operasional dan sumber lainnya diintegrasikan, dibersihkan dan diarsipkan untuk mendukung pengambilan keputusan. Menurut McLeod, data warehouse adalah sebuah sistem penyimpanan data yang berkapasitas besar, dimana data dikumpulkan dengan menambahkan record baru daripada meng-update record yang sudah ada dengan informasi baru. Data jenis ini digunakan khusus untuk proses pengambilan keputusan dan bukan untuk kegiatan operasional perusahaan sehari-hari. (Indrajani, menurut (Khotimah, 2016).

Data warehouse merupakan tempat penyimpanan data perusahaan atau institusi yang disusun sedemikian rupa sehingga mengandung makna dan digunakan untuk analisa dan pelaporan. Ada tiga hal atau lebih pendekatan untuk menyimpan data di data warehouse, pendekatan yang paling penting yaitu pendekatan dimensional dan pendekatan yang dinormalisasi . Jadi data warehouse adalah sumber informasi yang datanya diperoleh dari online pemrosesan transaksi (OLTP). Kebanyakan data warehouse menyimpan data yang bersifat historis, Seperti yang dikatakan Turban, menurut (Bhaskara et al., 2018), Datawarehouse Aronson dan Ting adalah data warehouse yang komprehensif database yang mendukung semua mendukung semua analisa keputusan yang diperlukan oleh perusahaan dengan memberikan ringkasan dan detail informasi.

Sedangkan menurut Connolly and Begg, menurut (Bhaskara et al., 2018), data warehouse adalah kumpulan data yang berorientasi pada subjek, terintegrasi, time-variant, dan non-volatile dalam mendukung proses pengambilan keputusan.

\section{Software}

Decision Support System (Sistem Pendukung Keputusan) sangat diperlukan bagi para pengambil keputusan pada setiap level manajemen. Informasi yang beragam perlu ditata dan dikompilasi dengan baik agar para pembuat keputusan dapat memutuskan keputusan dengan tepat. Marston et al, Rosadi \& Sidharta, menurut (Computech, 2018)

Software DSS siap pakai yang akan dianalisis yaitu Vanguard Busines Analytics Suite yang menggabungkan Analisis Keputusan, Time-Series Forecasting, Simulasi Monte Carlo, dan Optimasi ke dalam paket terintegrasi. Kraan \& Sherlock, menurut (Computech, 2018)

Software ini memungkinkan kita untuk menerapkan teknik analisis keputusan di seluruh perusahaan kita untuk masalah mulai dari proyek sederhana hingga rencana strategis enterprise. Chan, menurut (Computech, 2018).

Kemampuan kolaborasi Vanguard ini jauh melampaui strategi komunikasi sederhana seperti Web conferencing. Apalagi, Vanguard didasarkan pada prinsip-prinsip penangkapan pengetahuan. Individu diseluruh organisasi dapat menggunakan pendekatan inovatif berbasis model untuk menggambarkan ke Sistem Vanguard bagaimana mereka membuat keputusan atau melakukan tugas tertentu. Dalam melakukan hal ini, user menangkap pengetahuan, atau keterampilan, yang khusus untuk bisnis kita. Sistem Vanguard dapat menggabungkan pengetahuan yang ditangkap oleh banyak individu untuk membuat Kecerdasan Kolektif yang berguna untuk menguji rencana bisnis dan mengotomatisasi operasi rutin. Pawlewski \& Otamendi, menurut (Computech, 2018). 


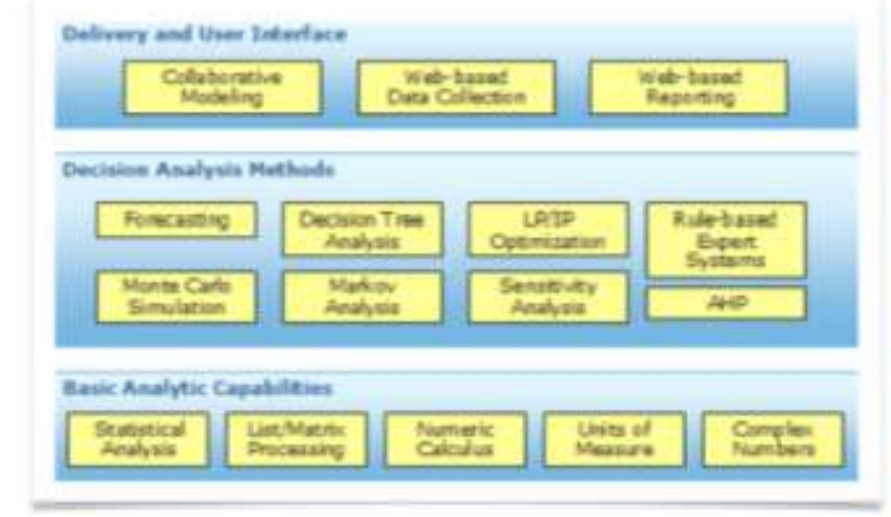

Gambar 1: Arsitektur layer kapabilitas Vanguard

Istilah dari decision support system, telah digunakan dengan banyak cara (Alter) dan menerima banyak definisi yang berbeda menurut pandangan dari sang penulis (Druzdzel dan Flynn). Finlay dan lainnya mendefiniskan DSS kurang lebih sebagai sebuah sistem berbasis komputer yang akan membantu dalam proses pengambilan keputusan.

Pengertian decision support system merupakan hasil pemecahan masalah yang harus didasari logika dan pertimbangan, penetapan alternatif terbaik, harus mendekati tujuan yang telah ditetapkan dan memperhatikan hal-hal seperti logika, realitas, rasional, dan pragmatis. Keputusan keputusan selalu saling berhubungan, dan keputusan spesifik dapat mempengaruhi banyak individu dan kelompok dalam perusahaan atau sistem organisasi. Dasar-dasar keputusan Terry, menurut (Adiputra \& Mulyawan, 2019), adalah:

- Intuisi: keputusan diambil berdasarkan perasaan dan pemikiran si pengambil keputusan.

- Pengalaman: keputusan diambil berdasarkan kejadian-kejadian yang pernah dialami sebelumnya oleh si pengambil keputusan.

- Fakta: keputusan diambil berdasarkan data dan informasi yang telah dikumpulkan.

- Wewenang: keputusan diambil oleh pihak yang memiliki kekuasaan dan wewenang yang lebih tinggi.

- Rasional: keputusan yang diambil harus logis atau dapat diterima akal sehat.

Pengambilan keputusan merupakan hasil suatu proses pemilihan dari berbagai alternatif Tindakan Turban, menurut ( Harry putra 2016) mendefinisikan secara lebih spesifik dengan, sesuatu yang interaktif, flexible dan bisa menyesuaikan diri (adaptable) dari sistem informasi berdasarkan komputer, khususnya pengembangan untuk mendukung pemecahan masalah dari non-struktur management, untuk dapat meningkatkan pengambilan keputusan. Dengan menggunakan data, mendukung antar muka yang mudah digunakan dan memberikan wawasan untuk para pengambil keputusan.

Decision Support System merupakan sistem informasi interaktif yang menyediakan informasi, pemodelan dan pemanipulasian data. Sistem itu digunakan untuk membantu pengambilan keputusan dalam situasi yang semi terstruktur dan situasi yang tidak terstruktur, dimana tak seorang pun tahu secara pasti bagaimana keputusan seharusnya dapat dibuat Kusrini, menurut (Zulkifli, 2016).

Decision Support System menurut Efrain Turban adalah sistem berbasis komputer interaktif, yang membantu para pengambil keputusan untuk menggunakan data dan berbagai model untuk memecahkan masalah tidak terstruktur. Menggunakan kombinasi dari model, 
teknik analisis dan pengambilan informasi sistem seperti membantu mengembangkan dan mengevaluasi alternatif yang sesuai.

Decision Support System dirancang secara khusus untuk mendukung seseorang yang harus mengambil keputusankeputusan tertentu Budi S, menurut (Zulkifli, 2016). Berikut ini beberapa kriteria sistem pendukung keputusan:

- Interaktif, Decision Support System memiliki user interface yang komunikatif, sehingga pemakai dapat melakukan akses secara cepat ke data dan memperoleh informasi yang dibutuhkan.

- Fleksibel, Decision Support System memiliki sebanyak mungkin variabel masukan, kemampuan untuk mengolah dan memberikan keluaran yang menyajikan alternatifalternatif keputusan kepada pemakai.

- Data Kualitas Decision Support System memiliki kemampuan untuk menerima data kualitas yang dikuantitaskan yang sifatnya subyektif dari pemakainya, sebagai data masukan untuk pengolahan data.

- Prosedur Pakar Decision Support System mengandung suatu prosedur yang direncanakan berdasarkan rumusan formal atau juga berupa prosedur kepakaran seseorang atau kelompok dalam menyelesaikan suatu bidang masalah dengan fenomena tertentu.

Decicion Support Systems merupakan sekumpulan prosedur berbasis model untuk data pemrosesan dan penilaiaan guna dapat membantu para manajer mengambil keputusan Littel , menurut (Muslihudin \& Amrullah, 2016).

Dia menyatakan bahwa untuk sukses, system tersebut haruslah sederhana, cepat, dan mudah dikontrol. Moore dan Chang, menurut (Muslihudin \& Amrullah, 2016) berpendapat bahwa konsep struktur, seperti yang banyak disinggung pada definisi awal DSS (bahwa DSS dapat menangani situasi semi tersetruktur dan tidak tersetruktur), secara umum tidak penting; semuah masalah dapat dijelaskan sebagai masalah tersetruktur dan tidak tersetruktur hanya dengan memperhatikan para pengambil keputusan atau suatu situasi spesifik (yakni keputusan tersetruktur adalah tersetruktur karena kita memilih untuk memperlakukanya dengan cara seperti itu). Jadi, mereka mendefinisikan DSS sebagai system yang dapat di perluas untuk mampu mendukung analisis data ad hoc dan pemodelan keputusan, berorentasi terhadap perancangan masa depan, dan digunakan interval yang tidak regular dan tak terencana.

Decision Support System (DSS) adalah sebuah sistem yang mampu memberikan kemampuan pemecahan masalah maupun kemampuan pengkomunikasian untuk masalah dengan kondisi semi terstruktur dan tak terstruktur. Sistem ini digunakan untuk membantu pengambilan keputusan dalam situasi semi terstruktur dan situasi yang tidak terstruktur, dimana tak seorangpun tahu secara pasti bagaimana keputusan seharusnya dibuat (Turban). Secara umum Decision Support System dibangun oleh tiga komponen besar yaitu database Management, Model Base dan Software System/User Interface. Komponen Decision Support System tersebut dapat digambarkan seperti gambar di bawah ini. 


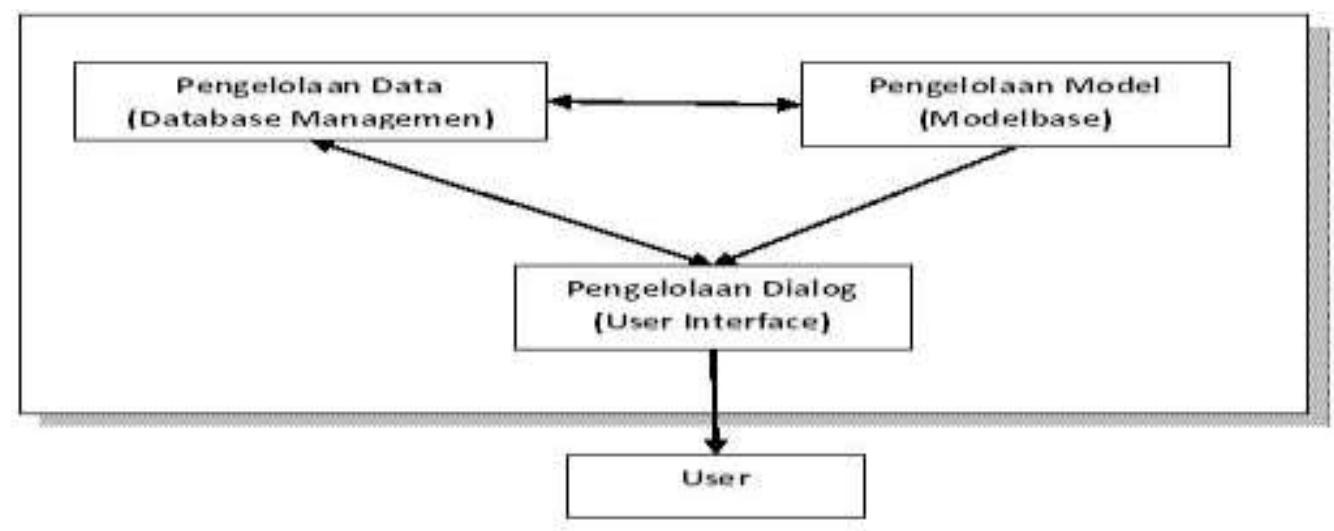

Gambar 2: Komponen Decision Support System

Decision Support System telah berkembang secara signifikan sejak perkembangan awal mereka di tahun 1970-an. Selama tiga dekade terakhir, Decision Support System telah mengambil definisi yang lebih sempit atau lebih luas, sementara sistem lainnya juga telah muncul untuk membantu jenis pembuat keputusan tertentu yang menghadapi jenis masalah tertentu. Salah satu definisi pertama diberikan oleh Keen dan Morton, menurut (Fenu \& Malloci, 2020) yang mendefinisikan Decision Support System sebagai sistem komputer yang mengumpulkan sumber daya dan menggunakan kemampuan komputer untuk meningkatkan kualitas keputusan dengan berfokus pada masalah semi terstruktur. Dan juga, Decision Support System didefinisikan sebagai sistem manusia-komputer yang mengumpulkan informasi, memproses informasi, dan menyediakan informasi berdasarkan sistem komputer. Namun, para peneliti setuju bahwa tujuan utama Decision Support System adalah untuk mendukung dan mempercepat pengambilan keputusan. Decision Support System dapat terdiri dari empat subsistem utama yaitu subsistem Manajemen Data, subsistem Manajemen Model, subsistem Berbasis Pengetahuan dan subsistem Antarmuka user. Fungsionalitas dari subsistem Manajemen Data adalah untuk mengelola data yang akan digunakan sebagai informasi untuk mengambil keputusan pada subsistem berbasis Pengetahuan. Komponen Model terdiri dari berbagai model yang dapat membantu pengambil keputusan dalam pengambilan keputusan. Berbasis pengetahuan adalah inti dari sistem dan mengelola proses pemecahan masalah untuk menghasilkan solusi akhir. Antarmuka Pengguna memungkinkan user untuk mendorong interaksi dengan sistem untuk memperoleh informasi. Secara umum, Decision Support System telah diklasifikasikan menjadi tiga kategori berdasarkan masalah untuk pengambilan keputusan: terstruktur, tidak terstruktur dan semi-terstruktur.

\section{Brainware}

Adapun komponen sistem informasi manajemen menurut Susanto , (Alfriza Frisdayanti, 2019) yaitu;

1) Hardware yaitu: peralatan phisik yang dapat digunakan untuk mengumpulkan, memasukkan, memproses, menyimpan, dan mengeluarkan hasil pengolahan data dalam bentuk informasi,

2) Software yaitu: kumpulan dari program-program yang digunakanuntuk menjalankan komputer atau aplikasi tertentu pada computer,

3) Brainware atau sumber daya manusia yaitu bagian terpenting dari komponen sistem informasi manajemen, 
4) Prosedur yaitu rangkaian aktivitas atau kegiatan yang dilakukan secara berulang-ulang dengan cara yang sama,

5) Basis data yaitu suatu pengorganisasian sekumpulan data yang saling terkait sehingga memudahkan proses pencarian informasi, dan

6) Jaringan komputer dan komunikasi data.

Brainware merupakan orang yang memiliki, membangun dan menjalankan sistem informasi manajemen. Istilah orang disini bukan sembarang orang dalam arti wujudnya orang akan tetapi orang yang memiliki kompetensi (knowledge dan keterampilan atau keahlian). Misalnya, Programer yaitu membuat atau menyempurnakan program komputer yang digunakan saat ini. Programer harus memiliki kompetensi (knowledge dan keterampilan atau keahlian) dan sesuai dengan jenjangnya mengenai sistem informasi, memiliki pendidikan minimal D3 ilmu komputer dan informasi, atau berpengalaman di bidang komputer akuntansi. Brainware dikelompokan sebagai berikut:

a) Manajer system informasi (manajemen/akuntansi),

b) Analis sistem,

c) Ahli komunikasi,

d) Administrator database,

e) Programer,

f) Operator, dan Pustakawan.

Integrasi komponen brainware mengandung arti semua kelompok brainware tersebut harus dapat bekerja sama secara harmonis dalam mendukung beroperasinya sistem informasi manajemen. Brainware (User) merupakan para personil yang terlibat langsung dalam pemakaian komputer, seperti sistem analis, programmer, operator, user, dll. Pada organisasi yang cukup besar, masalah komputerisasi biasanya ditangani oleh bagian khusus yang dikenal dengan bagian EDP (Electronic Data Processing), atau sering disebut dengan EDP Departemen, yang dikepalai oleh seorang Manager EDP.

Kristanto, menurut (Madela \& Ginting, 2021) mengemukakan Analis Sistem adalah individu yang memiliki kemampuan untuk melakukan analisis terhadap suatu sistem, memilih solusi untuk memecahkan problem (problem solving) dan menuntaskan masalah yang ada dengan memanfaatkan komputer. Maka, analis sistem itu merupakan seorang individu yang dianggap sebagai kunci dalam proses pengembangan suatu sistem. Seorang analis sistem harus memiliki minimal empat keahlian : analitis, teknis, manajerial, dan sosial (berkomunikasi dengan orang lain) Sebuah sistem akan didesain oleh satu individu atau sekelompok individu yang membentuk suatu tim. Individu yang mendesain sistem tersebut dinamakan System Analyst. Beberapa orang mendefinisikan analis sistem sebagai:

- Seseorang yg memanfaatkan wawasan aplikasi computer yang ia punya guna dapat menuntaskan permasalahan-permasalahan yang ada dalam sebuah bisnis, dibawah arahan manajer sistem.

- Seseorang yang memiliki tanggungjawab mengartikan keperluan-keperluan si pengguna sistem atau biasa disebut user ke dalam spessifikasi teknik yang dibutuhkan oleh programmer dan dipantau oleh manajemen.

System analyst adalah Sumber Daya Manusia yang tugasnya mengumpulkan kasuskasus proses bisnis yang akan diubah ke IT dan menampilkan dalam bahasa atau spesifikasi teknis yang mudah dipahami oleh programmer. Sehingga mereka mengetahui betul proses 
bisnis di lingkungan dan mempunyai pengetahuan IT. Sedangkan, profesi ini jarang yang berpengaruh karena tugasnya hanya musiman dan biasanya seorang programmer mampu melakukannya sendiri. Karena itu, fungsi system analyst biasanya dilakukan oleh salah satu seorang programmer.

Edi Purwono, menurut (triya, 2020) brainware adalah seorang ahli professional yang secara langsung terlibat dalam pengolahan sebuah system informasi. Orang-orang yang ahli tersebut antara lain bagian system analis dan juga programmer.Azhar Susanto, menurut (triya, 2020) dalam bukunya yang berjudul system informasi manajemen, Brainware merupakan sumber daya yang terlibat didalam pembuatan system informasi, pengumpulan, pengolahan data, pendistribusian,dan pemanfaatan informasi yang dihasilkan oleh system informasi.

Brainware sebagai factor manusia yang menangani system informasi Sanyoto Gondodiyoto, menurut (triya, 2020) ditujukan untuk menjelajahi kemampuan hardware dan software yang terdapat (terinstall) pada sebuah komputer. Fungsi Brainware bermacam-macam diantaranya sebagai pengguna komputer, melakukan input data dan pemanfaatan output data, serta menyusun perangkat software dan hardware komputer

\section{Pengambilan keputusan}

Pengambilan Keputusan Salah satu fungsi fundamental dalam kepimpinan, untuk lebih spesifik, manajer lebih melihat waktu, perhatian, pertimbangan, dan pengkajian digunakan untuk melihat siklus pengambilan keputusan. Pengambilan Keputusan dilakukan dengan tepat dan akurat dari posisi seorang manajer, yang akan menjadi tugas utama yang harus diselesaikan. Kegiatan dan metode pemimpin dalam melakukan penyelesaian pilihan secara signifikan mempengaruhi aktivitas dan mentalitas stafnya. Pengambilan keputusan adalah konsekuensi dari pemikiran kritis, tanggapan terhadap penyelidikan adalah hukum keadaan, dan merupakan pilihan salah satu pilihan dari pilihan lain yang ada, sama seperti hasil dari perspektif tentang masalah saat ini. SIM dibentuk guna mendorong keputusan-keputusan manajemen pada area-area problema tertentu adalah decision support system (DSS). Jadi DSS =SIM dan SIM= DSS. Konsisten DSS itu pemusatannya lebih besar pada pengambilan keputusan, sedangkan SIM pemfokusan lebih pada penyampaian informasi. Jadi sistem informasi manajemen adalah alat penyaji informasi. Informasi apa yang harus disajikan, bagaimana rupa dan kareteristik SIM itu sendiri sangat ditentukan oleh fungsi yang dipikulnya. Dalam hal ini fungsi adalah pengambilan keputusan. Untuk dapat melakukan urusan-urusan dalam cara pengambilan keputusan, maka dibutuhkan informasi-informasi yang bermutu (akurat, tepat waktu, relevan). Pengambilan keputusan bertujuan tunggal, apabila terjadi keputusan yang dihasilkan hanya menyangkut pada satu masalah. Artinya, sekali diputuskan tidak akan ada berkaian dengan masalah lain, keputusan yang dihasilkan menyangkut lebih dari satu masalah akan menjadi bersifat ganda, artinya keputusan yang diambil langsung menyelesaikan pada 2 masalah atau lebih,yang bersifat kontradiktif atau yang tidak kontradiktif, menurut (Informasi et al., 2021)

Terry George dan Barnard, I, Chester, menurut (Sudjiman, 2018) menjelaskan bahwa proses penurunan suatu keputusan mengandung empat unsur:

1. Model yang menunjukkan gambaran suatu masalah secara kuantitatif atau kualitatif.

2. Kriteria yang dirumuskan menunjukkan tujuan dari keputusan yang diambil. Jika terdapat beberapa kriteria yang saling bertentangan, maka pengambilan keputusan 
harus melalui kompromi (misalnya menambah jasa Iangganan dan mengurangi persediaan, maka keputusan mana yang diambil perlu kompromi).

3. Pembatas yaitu Faktor - faktor tambahan yang perlu diperhatikan dalam memecahkan masalah pengambilan keputusan. Misalnya dana yang kurang tersedia.

4. Optimalisasi yaitu Apabila masalah keputusan telah diuraikan dengan sejelas jelasnya, maka manajer menentukan apa yang diperlukan (kriteria) dan apa yang diperbolehkan (pembatas). Pada keadaan ini pengambil keputusan siap untuk memilih pemecahan yang terbaik atau yang optimal.

Menurut (Ali, 2010) dalam bukunya Sistim Informasi Bisnis, tentang Proses pembuatan keputusan. Tidak ada pendekatan pembuatan keputusan yang bisa menjamin manajer akan selalu membuat keputusan yang benar. Tetapi bagaimanapun juga para manajer menggunakan pendekatan yang rasional, intelektual, sistematik akan lebih berhasil dibanding para manajer yang menggunakan pendekatan informal.

Menurut Tjiptono (Yunita \& Ali, 2017), pengambilan keputusan adalah proses yang dimulai dari pengenalan masalah melalui analisa beberapa produk.

Tabel 1: Penelitian terdahulu

\begin{tabular}{|c|c|c|c|c|}
\hline No & Author (tahun) & Hasil Riset terdahulu & $\begin{array}{c}\text { Persamaan dengan artikel } \\
\text { ini }\end{array}$ & $\begin{array}{l}\text { Perbedaan dengan } \\
\text { artikel ini }\end{array}$ \\
\hline 1. & $\begin{array}{l}\text { (Gunadi \& } \\
\text { Widianto,2020) }\end{array}$ & $\begin{array}{l}\text { Data warehouse dengan } \\
\text { metode krytografi } \\
\text { mendukung analisa } \\
\text { keputusan. }\end{array}$ & $\begin{array}{l}\text { Data warehouse } \\
\text { berpengaruh terhadap } \\
\text { pengambilan keputusan }\end{array}$ & $\begin{array}{l}\text { Metode krytografi } \\
\text { berpengaruh terhadap } \\
\text { pengambilan } \\
\text { keputusan }\end{array}$ \\
\hline 2. & $\begin{array}{l}\text { (Khotimah, } \\
\text { 2016) }\end{array}$ & $\begin{array}{l}\text { Data warehouse melayani } \\
\text { informasi strategis }\end{array}$ & $\begin{array}{l}\text { Data warehouse } \\
\text { berpengaruh terhadap } \\
\text { pengambilan keputusan }\end{array}$ & $\begin{array}{l}\text { Metode Kimball } \\
\text { berpengaruh atas } \\
\text { pengambilan analisa } \\
\text { keputusan }\end{array}$ \\
\hline 3. & $\begin{array}{l}\text { (Bhaskara et } \\
\text { al., 2018) }\end{array}$ & $\begin{array}{l}\text { Data warehouse } \\
\text { mendukung terhadap } \\
\text { informasi penjualan }\end{array}$ & $\begin{array}{l}\text { Data warehouse } \\
\text { berpengaruh terhadap } \\
\text { pengambilan keputusan }\end{array}$ & $\begin{array}{l}\text { MOLAB berpengaruh } \\
\text { terhadap pengambilan } \\
\text { keputusan }\end{array}$ \\
\hline 4. & $\begin{array}{l}\text { ( Sepsugiarto, } \\
\text { S, 2011) }\end{array}$ & $\begin{array}{l}\text { Data warehouse terhadap } \\
\text { pengambilan keputusan } \\
\text { bagian penjualan }\end{array}$ & $\begin{array}{l}\text { Data warehouse } \\
\text { berpengaruh terhadap } \\
\text { pengambilan keputusan }\end{array}$ & $\begin{array}{l}\text { Data warehouse } \\
\text { berpengaruh terhadap } \\
\text { analisa penjualan }\end{array}$ \\
\hline 5. & $\begin{array}{l}\text { (Adiputra, R., } \\
\text { \& Mulyawan, } \\
\mathrm{B}, 2019 \text { ). }\end{array}$ & $\begin{array}{l}\text { Aplikasi software (DSS) } \\
\text { yang membantu } \\
\text { mengambil keputusan } \\
\text { untuk pemilihan vendor }\end{array}$ & $\begin{array}{l}\text { Software (DSS) } \\
\text { berpengaruh terhadap } \\
\text { pengambilan keputusan }\end{array}$ & $\begin{array}{l}\text { Metode Weighted } \\
\text { Product berpengaruh } \\
\text { terhadap pengambilan } \\
\text { keputusan. }\end{array}$ \\
\hline 6. & (Zulkifli, 2016) & $\begin{array}{l}\text { Aplikasi software (DSS) } \\
\text { yang membantu } \\
\text { mengambil keputusan } \\
\text { pemberian bonus } \\
\text { berdasarkan kinerja } \\
\text { karyawan. }\end{array}$ & $\begin{array}{l}\text { Software (DSS) } \\
\text { berpengaruh terhadap } \\
\text { pengambilan keputusan }\end{array}$ & $\begin{array}{l}\text { Metode Simple } \\
\text { Additive Weighting } \\
\text { berpengaruh terhadap } \\
\text { pengambilan } \\
\text { keputusan pemberian } \\
\text { bonus. }\end{array}$ \\
\hline 7. & $\begin{array}{l}\text { (Muslihudin \& } \\
\text { Amrullah, } \\
\text { 2016). }\end{array}$ & $\begin{array}{l}\text { Model DSS dalam } \\
\text { mendukung pengambil } \\
\text { keputusan untuk } \\
\text { mengetahui tingkat } \\
\text { bahaya asap kendaraan }\end{array}$ & $\begin{array}{l}\text { Software (DSS) } \\
\text { berpengaruh terhadap } \\
\text { pengambilan keputusan }\end{array}$ & $\begin{array}{l}\text { Metode Fuzzy } \\
\text { Multiple Attribute } \\
\text { berpengaruh terhadap } \\
\text { pengambilan } \\
\text { keputusan }\end{array}$ \\
\hline 8. & $\begin{array}{l}\text { Fenu \& } \\
\text { Malloci, 2020) }\end{array}$ & $\begin{array}{l}\text { Aplikasi DSS dalam } \\
\text { pengambilan keputusan } \\
\text { pada sector pertanian }\end{array}$ & $\begin{array}{l}\text { Software (DSS) } \\
\text { berpengaruh terhadap } \\
\text { pengambilan keputusan }\end{array}$ & $\begin{array}{l}\text { Model prognosis dan } \\
\text { model fry berpengaruh } \\
\text { terhadap pengambilan } \\
\text { keputusan }\end{array}$ \\
\hline
\end{tabular}




\begin{tabular}{|l|l|l|l|l|}
\hline 9. & $\begin{array}{l}\text { (Alfriza } \\
\text { Frisdayanti, } \\
\text { 2019) })\end{array}$ & $\begin{array}{l}\text { Brainware dalam sistim } \\
\text { informasi akan } \\
\text { menghasilkan informasi } \\
\text { yang akurat dan detail }\end{array}$ & $\begin{array}{l}\text { Brainware berpengaruh } \\
\text { terhadap pengambilan } \\
\text { keputusan }\end{array}$ & $\begin{array}{l}\text { Sistim informasi } \\
\text { berpengaruh terhadap } \\
\text { pengambilan } \\
\text { keputusan. }\end{array}$ \\
\hline 10. & $\begin{array}{l}\text { (Madela \& } \\
\text { Ginting, 2021) }\end{array}$ & $\begin{array}{l}\text { Analis sistem } \\
\text { (brainware) bertindak } \\
\text { sebagai perencana } \\
\text { strategis dan konsultan } \\
\text { teknologi data }\end{array}$ & $\begin{array}{l}\text { Brainware berpengaruh } \\
\text { terhadap pengambilan } \\
\text { keputusan }\end{array}$ & $\begin{array}{l}\text { Brainware berpengaruh } \\
\text { terhadap pemecahan } \\
\text { masalah }\end{array}$ \\
\hline 11. & (triya, 2020) & $\begin{array}{l}\text { Brainware dalam } \\
\text { menghasilkan informasi } \\
\text { dan data yang berkualitas }\end{array}$ & $\begin{array}{l}\text { Brainware berpengaruh } \\
\text { terhadap pengambilan } \\
\text { keputusan }\end{array}$ & $\begin{array}{l}\text { Brainware berpengaruh } \\
\text { terhadap output } \\
\text { infirmasi dan data yang } \\
\text { berkualitas }\end{array}$ \\
\hline
\end{tabular}

\section{METODE PENULISAN}

Metode penulisan artikel ilmiah ini adalah dengan metode kualitatif dan studi literature atau Library Research. Mengkaji Buku-buku literature sesuai dengan teori yang di bahas khusunya di lingkup Executive Support Sistem (ESS) For Business Disamping itu menganalisis artikel-artikel ilmiah yang bereputasi dan juga artikel ilmiah dari jurnal yang belum bereputasi. Semua artikel ilmiah yang di citasi bersumber dari Mendeley dan Scholar Google.

Dalam penelitian kualitatif, kajian pustaka harus digunakan secara konsisten dengan asumsiasumsi metodologis. Artinya harus digunakan secara induktif sehingga tidak mengarahkan pertanyaan-pertanyaan yang diajukan oleh peneliti. Salah satu alasan utama untuk melakukan penelitian kualitatif yaitu bahwa penelitian tersebut bersifat eksploratif.

Selanjutnya dibahas secara mendalam pada bagian yang berjudul" Pustaka Terkait" (Related Literature) atau Kajian pustaka ( "Review of Literature"), sebagai dasar perumusan hipotesis dan selanjutnya akan menjadi dasar untuk melakukan perbandingan dengan hasil atau temuantemuan yang terungkap dalam penelitian.

Inclusion creteria

Tahapan untuk memutuskan apakah data yang ditemukan ada korelasi dan layak digunakan untuk penelitian literature review, dengan kriteria sebagai berikut:

1. Data yang digunakan dalam rentang waktu $2016-2021$.

2. Data yang diperoleh melalui situs https://harzing.com/resources/publish-or-perish dan https://ww.google.com.

3. Data yang digunakan berhubungan dengan data warehouse, software, brainware dan pengambilan keputusan.

\section{PEMBAHASAN}

Artikel ini menganalis dan membahas tentang variabel-variabel Sistim Informasi yaitu: Data warehouse, software, brainware dan pengambilan keputusan. Dimana data warehouse, software dan brainware berpengaruh terhadap pengambilan keputusan. Riset dan artikel terdahulu dan relevan dengan artikel ini di antarnya adalah:

1. Data warehouse berpengaruh terhadap pengambilan keputusan

Data warehouse adalah sebuah basis data komprehensif yang mendukung semua analisis keputusan yang diperlukan oleh suatu perusahaan dengan menyediakan 
ringkasan dan rincian informasi, Mengutip dari Jurnal (Muhammad Rifqi, Rusdah, Moedjiono, menurut (Gunadi \& Widianto, 2020))

Inmon (2002) menurut (Sepsugiarto, 2011), data warehouse adalah data yang berorientasi pada subyek, terintegrasi, non volatile dan kumpulan data dari berbagai waktu yang digunakan untuk mendukung pengambilan keputusan.

Data warehouse merupakan tempat penyimpanan data perusahaan atau institusi yang disusun sedemikian rupa sehingga mengandung makna dan digunakan untuk analisa dan pelaporan. Seperti yang dikatakan Turban (menurut (Bhaskara et al., 2018),

Penggunaan data warehouse pada dasarnya dilakukan oleh end-user dan pada umumnya dilakukan oleh para bisnisman atau seorang teknikal. Keputusan utama yang diperlukan oleh seorang bisnisman adalah mengenai kesehatan dan kelangsungan hidup bisnis itu sendiri. Pengambil keputusan biasanya berpikir mengenai pangsa pasar yang ada, keuntungan yang dicapai, pesaing yang ada, biaya yang dikeluarkan, efisiensi dan kualitas produksi (Immon, 2002), menurut (Sepsugiarto, 2011)

Dari sumber-sumber tersebut bahwa menunjukkan data warehouse adalah data koprehensif dan sangat mendukung pada pengambilan keputusan, yang diperlukan untuk analisa sebelum mengambil keputusan.

2. Software berpengaruh terhadap pengambilan keputusan

DSS merupakan sistem informasi interaktif yang menyediakan informasi, pemodelan dan pemanipulasian data. Sistem itu digunakan untuk membantu pengambilan keputusan dalam situasi yang semi terstruktur dan situasi yang tidak terstruktur, dimana tak seorang pun tahu secara pasti bagaimana keputusan seharusnya dibuat (Kusrini,2007, menurut (Zulkifli, 2016).

Decicion Support Systems merupaka sekumpulan prosedur berbasis model untuk data pemrosesan dan penilaiaan guna membantu para manajer mengambil keputusan (Littel 1970, menurut (Muslihudin \& Amrullah, 2016)

(McLeod:1995). Menurut (Zulkifli, 2016) Setelah pernyataan tersebut, beberapa perusahaan dan perguruan tinggi melakukan riset dan mengembangkan konsep Decision Support System. Pada dasarnya DSS dirancang untuk mendukung seluruh tahap pengambilan Jurnal TAM (Technology Acceptance Model) Volume 7, Desember 201668 keputusan mulai dari mengidentifikasi masalah, memilih data yang relevan, menentukan pendekatan yang digunakan dalam proses pengambilan keputusan sampai mengevaluasi pemilihan alternatif.

Decision Support System (DSS) adalah sebuah sistem yang mampu memberikan kemampuan pemecahan masalah maupun kemampuan pengkomunikasian untuk masalah dengan kondisi semi terstruktur dan tak terstruktur.Sistem ini digunakan untuk membantu pengambilan keputusan dalam situasi semi terstruktur dan situasi yang tidak terstruktur, dimana tak seorangpun tahu secara pasti bagaimana keputusan seharusnya dibuat (Jumarlis, 2020), menurut (Jumarlis, 2021)

Dari sumber-sumber tersebut menunjukkan software aplikasi DSS membantu para manajer dalam pemrosesan dan penilaian data, yang menjadikan suatu informasi, 
pemodelan dan pemanipulasian data, yang sangat membantu dalam pengambilan keputusan.

3. Brainware berpengaruh terhadap pengambilan keputusan .

Menurut Edi Purwono (2004), menurut (triya, 2020) brainware adalah seorang ahli professional yang secara langsung terlibat dalam pengolahan sebuah system informasi. Orang-orang yang ahli tersebut antara lain bagian system analis dan juga programmer. Menurut Azhar Susanto (2017: 188) menurut (triya, 2020) dalam bukunya yang berjudul system informasi manajemen, Brainware merupakan sumber daya yang terlibat dalam pembuatan system informasi, pengumpulan, pengolahan data, pendistribusian, dan pemanfaatan informasi yang dihasilkan oleh system informasi.

Menurut (Ali, 2009) Brainware adalah manusia atau sumber daya manusia (SDM) yang mempunyai keahlian khusus mengenai pengolahan data dengan komputer.

Dari sumber-sumber tersebut menunjukkan brainware, baik sebagai pemilik atau pemakai sistim informasi akan menentukan masalah yang harus dipecahkan atau kebetuhan yang harus dipenuhi, yang sangat membantu didalam pengambilan keputusan.

\section{Conceptual Framework}

Berdasarkan Kajian teori dan hubungan antar variabel maka model atau Conceptual Framework artikel ini dalam rangka menbagunan hipotesis adalah sebagai berikut:

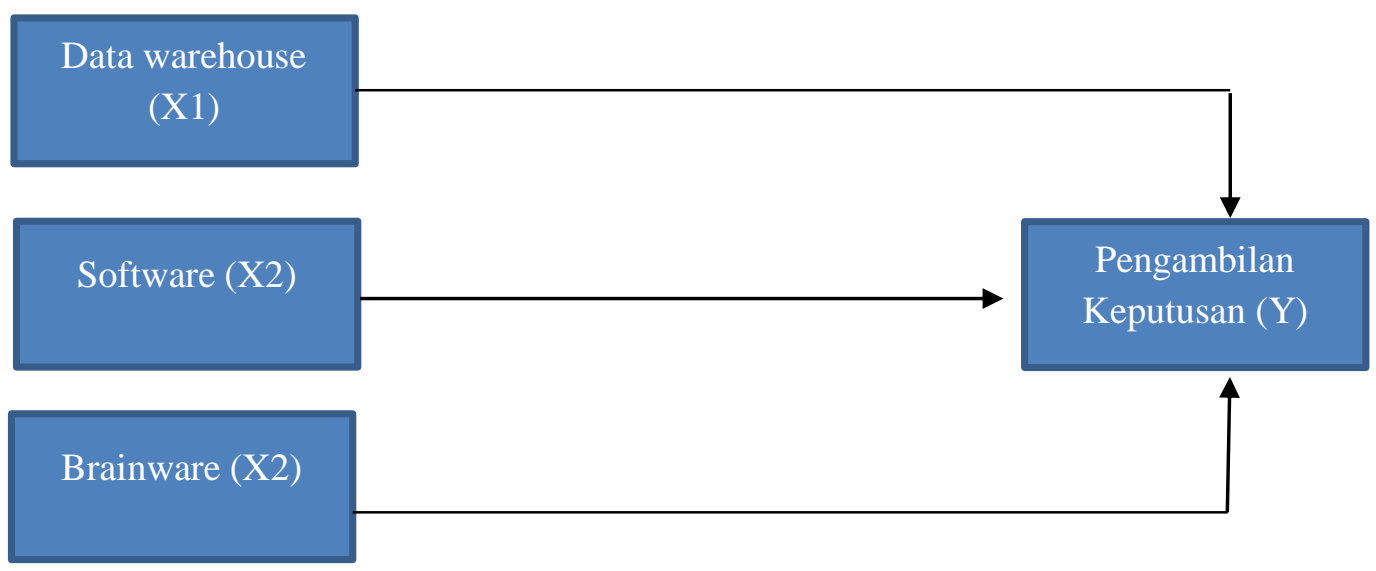

Gambar 3: Conceptual Framework

Data warehouse (X1), Software (X2) dan Brainware (X3) terhadap pengambilan keputusan (Y). Variabel lain (epsilon) yang diduga mempengaruhi proses pengambilan keputusan adalah Selain dari 3 variabel exogen ini juga yang mempengaruhi pengambilan keputusan (Y), masih banyak variabel lain yang mempengaruhinya diantaranya adalah:

1) Hardware : ( CK Sastradipraja, 2021) dan ((Kusuma, 2016)

2) Jaringan komunikasi : (Sumardi \& Zaen, 2018) dan (Dinas et al., 2018)

3) Teknologi Informasi: (Sari \& Ali, 2019), (Shobirin \& Hapzi Ali, 2019) 


\section{KESIMPULAN DAN SARAN}

Kesimpulan

Berdasarkan pembahasan, maka dapat disimpulkan untuk membangun suatu hipotesis guna untuk riset selanjutnya seperti di bawah ini:

1) Data warehouse berpengaruh terhadap Pengambilan Keputusan, dikarenakan sifat dari data warehouse yang merupakan data yang komprehensif, sehingga sangat mendukung pada pengambilan keputusan.

2) Software berpengaruh terhadap Pengambilan Keputusan, hal tersebut ditunjukkan dengan software aplikasi DSS, yang sangat membantu seorang manajer dalam memproses dan menilai data, yang menghasilkan informasi yang akurat, dalam pengambilan keputusan.

3) Brainware berpengaruh terhadap Pengambilan keputusan, dikarenakan brainware terlibat langsung dalam pembuatan dan pemakaian sistim informasi tersebut, sehingga baik input ataupun output dari sistim tersebut sangat mendukung didalam pengambilan keputusan.

\section{Saran}

Bersdasarkan Kesimpulan di atas, maka saran pada artikel ini adalah bahwa masih banyak factor lain yang mempengaruhi Pengambilan Keputusan pada semua tipe dan level organisasi, oleh karena itu masih di perlukan kajian yang lebih lanjut untuk melengkapi factorfaktor lain apa sajakah yang dapat memepengaruhi Pengambilan keputusan. Faktor lain tersebut seperti Hardware (X4) dan Jaringan komunikasi (X5).

\section{DAFTAR PUSTAKA}

Adiputra, R., \& Mulyawan, B. (2019). Pembuatan Program Aplikasi Sistem Pendukung Keputusan Pemilihan Vendor Erp Pada Pt Sinar Jaya Abadi Dengan Menggunakan Metode Weighted Product. Ilmu Komputer Dan Sistem Informasi, 181-187.

Alfriza Frisdayanti. (2019). Peranan brainware dalam sistem informasi manajemen jurnal ekonomi dan manajemen sistem informasi. Jurnal Ekonomi Dan Manajemen Sistem Informasi, 1(September), 60-69. https://doi.org/10.31933/JEMSI

Ali, H. (2009). Sistem Informasi Manajemen Berbasis Teknologi Informasi. 199.

Ali, H. (2010). Sistem Informasi Bisnis Dalam Prospektif Keunggulan Kompetitif. 293.

Bhaskara, I. M. A., Suardani, L. G. P., \& Sudarma, M. (2018). Data Warehouse Implemantation

To Support Batik Sales Information Using MOLAP. IJEET (International Journal of Engineering and Emerging Technology), 3(1), 45-51.

Computech, J. (2018). ANALISIS SOFTWARE DUKUNGAN PENGAMBILAN KEPUTUSAN : VANGUARD BUSINES ANALYTICS Analisis Software Dukungan Pengambilan Keputusan: Vanguard Busines Analytics. 12(1), 1-10.

Dinas, D. I., Dan, K., Teknologi, P., \& Manado, U. N. (2018). KABUPATEN MINAHASA. 6(1). Fenu, G., \& Malloci, F. M. (2020). DSS LANDS: A Decision Support System for Agriculture in Sardinia. HighTech and Innovation Journal, 1(3), 129-135. https://doi.org/10.28991/hij-2020-01-03-05

Gunadi, F., \& Widianto, S. R. (2020). Perbandingan Data Warehouse Cloud Computing Menggunakan Konvensional Berbasis Kriptografi. Seminar Nasional Teknologi Komputer \& Sains (SAINTEKS), 69-73. https://prosiding.seminarid.com/index.php/sainteks

Informasi, P. S., Sains, F., \& Teknologi, D. (2021). KEPUTUSAN MANAJEMEN Rizky Akbar Siregar.

Jumarlis, M. (2021). Sistem Pengambilan Keputusan Pemilihan Bibit Ikan Air Tawar untuk Dibudidayakan Menggunakan Metode AHP Berbasis Web. Inspiration: Jurnal Teknologi Informasi Dan Komunikasi, 11(1), 7. https://doi.org/10.35585/inspir.v11i1.2605

Khotimah, K. (2016). Perancangan Dan Implementasi Data Warehouse Untuk Mendukung 
Sistem Akademik (Studi Kasus Pada STKIP Muhammadiyah Kotabumi). Jurnal Teknologi Informasi Magister Darmajaya, 2(01), 94-107.

Kusuma, U. W. (2016). Penentuan Hardware dan Software Komputer menggunakan Weighted Product. 3(1), 47-52.

Madela, S., \& Ginting, B. (2021). Mini Tinjauan Perangkat Sumber Daya Manusia ( Brainware ): Analis Sistem. 0305202127.

Muslihudin, M., \& Amrullah, M. (2016). Model Dss Untuk Mengetahui Tingkat Bahaya Asap Kendaraan Menggunakan Metode Fuzzy Multiple Attribute Decision Making (Fmadm). Jurnal TAM, 6 , 9-14. http://ojs.stmikpringsewu.ac.id/index.php/JurnalTam/article/view/55/55

Sari, V. N., \& Ali, H. (2019). PERUMUSAN STRATEGI BAGI UNIVERSITAS PUTRA INDONESIA YPTK PADANG UNTUK MERAIH KEUNGGULAN BERSAING. Jurnal Ekonomi Manajemen Sistem Informasi. https://doi.org/10.31933/jemsi.v1i1.42

Sepsugiarto, S. (2011). Datawarehouse Sebagai Alat Penunjang Pengambil Keputusan Bisnis dalam Analisis Penjualan: Studi Kasus pada Bagian Penjualan PT XYZ. ComTech: Computer, Mathematics and Engineering Applications, 2(2), 835. https://doi.org/10.21512/comtech.v2i2.2834

Shobirin, M., \& Hapzi Ali. (2019). STRATEGI PENGEMBANGAN INFRASTRUKTUR DALAM MENINGKATKAN PELAYANAN PENUMPANG DI BANDAR UDARA INTERNASIONAL SOEKARNO HATTA CENGKARENG. Jurnal Ekonomi Manajemen Sistem Informasi. https://doi.org/10.31933/jemsi.v1i2.66

Sudjiman, P. E. S. dan L. S. (2018). KOMPUTER DALAM PROSES PENGAMBILAN KEPUTUSAN Paul Eduard Sudjiman dan Lorina Siregar Sudjiman COMPUTER BASED MANAGEMENT INFORMATION SYSTEM. Jurnal TeIKa, 8, 55-67.

Sumardi, S., \& Zaen, M. T. A. (2018). Perancangan Jaringan Komputer Berbasis Mikrotik Router OS Pada SMAN 4 Praya. Jurnal Informatika Dan Rekayasa Elektronik, 1(1), 50. https://doi.org/10.36595/jire.v1i1.32

triya, larasati. (2020). Brainware.

Yunita, D., \& Ali, H. (2017). Model of Purchasing Decision ( Renting ) of Generator Set: Analysis of Product Quality, Price an Service at PT . Hartekprima Listrindo. Economics, Business and Management, 4(11), 833-841. https://doi.org/10.21276/sjebm.2017.4.11.12

Zulkifli, S. (2016). Decision Support System Pemberian Bonus Tahunan Pada Karyawan Berdasarkan Kinerja Karyawan Menggunakan Metode Simple Additive Weighting (Study Kasus : Stmik Pringsewu). Jurnal TAM (Technology Acceptance Model), 7(0), 67-73. http://ojs.stmikpringsewu.ac.id/index.php/JurnalTam/article/view/74/74 